RASĀYAN J. Chem.

Vol. 14 | No. 2 |691-697| April - June | 2021 ISSN: 0974-1496 | e-ISSN: 0976-0083 | CODEN: RJCABP http://www.rasayanjournal.com http://www.rasayanjournal.co.in

\title{
THE PREPARATION OF MERBAU WOOD WASTE ASH- BASED CATALYST AND ITS UTILIZATION FOR BIODIESEL PRODUCTION FROM LOW-GRADE PALM OIL
}

\author{
D. Santi ${ }^{1, \bowtie}$, Triyono ${ }^{2}$ and J.V. Morin ${ }^{1}$ \\ ${ }^{1}$ Department of Chemistry, Faculty of Mathematics and Natural Sciences, University of Papua, \\ Manokwari-98312, Indonesia \\ ${ }^{2}$ Department of Chemistry, Faculty of Mathematics and Natural Sciences, University of Gadjah \\ Mada, Yogyakarta-55281, Indonesia \\ ${ }^{\bowtie}$ Corresponding Author: d.santi@unipa.ac.id
}

\begin{abstract}
The Merbau wood waste ash-based catalyst was prepared via various calcination temperatures and was applied for biodiesel production from low-grade palm oil. The thermal investigations of calcination of Merbau wood were carried out at temperatures of 500, 600, 700, 800, and $900{ }^{\circ} \mathrm{C}$ for $3 \mathrm{~h}$. It was led to $\mathrm{M} 700$ as a catalyst based on the highest basicity as confirmed by the basicity test and x-ray diffraction analysis. The M700 mass toward methanol volume ratio was performed at 5\%,10\%,15\%,20\% (w/v) on the application of conversion of LGPO into biodiesel. The products of biodiesel were prepared via reflux at temperature $80^{\circ} \mathrm{C}$ for $2 \mathrm{~h}$ and were characterized by GC-MS. The biodiesel product is predominantly methyl palmitate. The ash-methanol ratio of $15 \%$ gives the optimum biodiesel fraction conversion $(78.7 \% \mathrm{w} / \mathrm{w})$. The optimum selectivity of the yield total of biodiesel given by $10 \%$, namely $48.9 \% \mathrm{w} / \mathrm{w}$, resulted in methyl ester (biodiesel) with C15-C19 consisting of methyl myristate, methyl palmitate, methyl linoleate, methyl oleic, methyl stearate. Moreover, a 10\% weight catalyst to methanol showed the optimum decrease of FFA $(89.0 \pm 0.6 \%)$.

Keywords: Merbau Ash, Methyl Ester, Transesterification.
\end{abstract}

RASĀYAN J. Chem., Vol. 14, No.2, 2021

\section{INTRODUCTION}

The various bioenergy-focused has been an increase in research activity as well as the environmental concerns directed toward the development of a heterogeneous catalyst. Before that, the synthesis of heterogeneous catalysts for various applications such as molecular sieves ${ }^{1}$, hydrocracking catalytic ${ }^{2,3}$, and hydrogenation ${ }^{4}$, catalytic cracking ${ }^{5,6}$, biodiesel production. ${ }^{7-9}$

Biodiesel production by transesterification is a popular one, due to simpler methods and equipment. Using an appropriate catalyst, biodiesel could be derived either from plant oils or animal fats via an alcohol transesterification reaction. The various acid and base catalysts were needed in the transesterification process.

Some studies have given considerable attention to the production of acid, base, and heterogeneous metal oxide-based catalysts. $\mathrm{K}_{2} \mathrm{CO}_{3} / \mathrm{ZnO}$ was used as an alkaline catalyst within transesterification for biodiesel algae processing. ${ }^{10}$ This process resulted in oleic acid of $90.8 \%$ as the result of major fatty acid methyl ester (FAME). $\quad \mathrm{MgFe}_{2} \mathrm{O}_{4}-\mathrm{MgO}$ nanocomposite ${ }^{11}, \mathrm{KOH}^{12-14}, \quad \mathrm{LiNO}_{3} / \mathrm{Al}_{2} \mathrm{O}_{3}, \quad \mathrm{NaNO}_{3} / \mathrm{Al}_{2} \mathrm{O}_{3}$, $\mathrm{Mg}\left(\mathrm{NO}_{3}\right)_{2} / \mathrm{Al}_{2} \mathrm{O}_{3}, \mathrm{KNO}_{3} / \mathrm{Al}_{2} \mathrm{O}_{3}, \mathrm{Ca}\left(\mathrm{NO}_{3}\right)_{2} / \mathrm{Al}_{2} \mathrm{O}_{3}, \mathrm{~K}_{2} \mathrm{CO}_{3} / \mathrm{ZnO}$ Researchers have extensively studied alkali metal oxides, transition oxides, and mixed metal oxides for transesterification purposes. ${ }^{15}$ Positive metal oxide ions are defined as acceptors of electrons, whereas negative ions are referred to as acceptors of protons. In the adsorption process, contributions from electron and proton acceptors are needed.

The mechanism that occurs consists of four steps, namely: the first stage, the reaction between a catalyst of metal oxides or a mixture of metal oxides and methanol. The metal oxide cations must be sufficiently heavy to break the $\mathrm{O}-\mathrm{H}$ bond in methanol. The breaking of the bonds in $\mathrm{O}-\mathrm{H}$ from methanol is carried out by the catalyst, causing the formation of methoxy ions and hydrogen cations. In the second stage, the Rasayan J. Chem., 14(2), 691-697(2021)

http://dx.doi.org/10.31788/ RJC.2021.1426238

This work is licensed under a CC BY 4.0 license. 


\section{RASĀYAN J. Chem.}

Vol. 14 | No. 2 |691-697| April - June | 2021

methoxy ion acts as nucleophilic and attacks the alkoxide in the carbonyl group of triglycerides and forms an intermediate. In the third stage, the arrangement of the bonds in the intermediates will cause the formation of an alkyl ester and diglyceride ions present in alkoxide anions. In the fourth stage, the alkoxide ion will readily react with the available hydrogen cations in the first stage; at this stage, the catalyst undergoes deprotonation and reforms.

However, the use of catalysts by previous researchers used synthetic commercial catalysts which of course will have an environmental effect and is not renewable. Consequently, cheaper and environmental considerations have led to some heterogeneous catalyst research referring to waste treatment, such as rice husks ash ${ }^{16}$, palm kernel shell gasification residues ${ }^{17}$, walnut shell ash. ${ }^{18}$ Merbau wood waste ash contains the mineral of calcite $\left(\mathrm{CaCO}_{3}\right)$ of $50.1 \%-58.7 \%$ and mica/muscovite $\left(\mathrm{KAl}_{2}(\mathrm{OH})_{2} \mathrm{Si}_{3} \mathrm{AlO}_{10}\right)$ of $11.0 \%$ and $16.5 \%$ as part of its mineral components as written by Supit et al. ${ }^{19}$ The presence of alkaline or alkaline earth elements shows its potential as base catalysts in the transesterification reaction. This research studied the synthesis of Merbau wood waste ash with variations in calcination temperature. Furthermore, the activity and selectivity of the catalyst were studied through the effect of the weight of the catalyst on the methanol used.

\section{Material and Methods}

\section{EXPERIMENTAL}

The dried Merbau chips obtained from wood processing waste (Manokwari, Papua Barat, Indonesia), methanol (purity of 99.5\% from Merck), and low-grade palm oil (LGPO) were obtained from the local market. The other pro analytical chemicals of phenolphthalein indicator and $\mathrm{HCl}$ were all purchased from Merck.

\section{Synthesis of MWA-based Catalyst}

The MWA was synthesized by calcination under air at various temperatures ranging from $500-900{ }^{\circ} \mathrm{C}$ for a total of $3 \mathrm{~h}$ in a muffle furnace. Leading up to previous use, the calcinated catalyst was cooled down to room temperature. The solid materials were labelled respectively M500, M600, M700, M800, and M900. Then, these materials were characterized using a basicity test based on hydrogen chloride vapor acid absorption (mmol HCl.g $\mathrm{g}^{-1}$ ) and XRD analysis. The solid material with the highest basicity as confirmed by XRD at the varied temperatures of calcination was tested in the catalyst activity and selectivity test in the transesterification reaction.

\section{Transesterification of LGPO}

M700 which has the highest overall basicity and crystalline phase evaluated its catalytic activity. The transesterification was performed with four forms of variations to ensure optimum results of decrease in FFA levels of LGPO. Varied of the mass of the catalyst versus methanol of $5 \%, 10 \%, 15 \%, 20 \%(\mathrm{w} / \mathrm{v})$. The solid of M700 is mixed with $75 \mathrm{~mL}$ of methanol and then stirred for 48 hours at room temperature. The catalyst and methanol mixture is reacted with LGPO with a mole ratio of the catalyst system to the oil of 6:1. This mixture was poured into a conical flask made up of three-neck jars. The system is stored on a heating mantel and is operated for $2 \mathrm{~h}$ at a continuous temperature of $80^{\circ} \mathrm{C}$. At a steady speed of $250 \mathrm{rpm}$, the liquid in the flask is stirred. The result was formed a two-layer solution. The bottom layer was glycerine and the upper layer is methyl ester. The collected biodiesel product was characterized by GC-MS. The activity catalytic performance was shown by the amount of reduction in FFA levels. The selectivity ability was shown from the type of compound confirmed by GC MS analysis.

\section{Detection Method}

Characterization of MWA-based catalyst was recorded using an X-ray diffractogram (XRD-Rigaku Miniflex600, $\lambda=1.54 \AA, 40 \mathrm{kV}, 15 \mathrm{~mA}$ ). An acid-base titration was carried out using $0.1 \mathrm{~N} \mathrm{HCl}$, a method of quantitative analysis for determining the concentration of MWA-based catalyst by exactly neutralizing it with a standard solution of an acid having a known concentration. The collected biodiesel product was analyzed using Gas Chromatography-Mass spectrometer (GC-MS, Shimadzu QP2010S) with a column length of $30 \mathrm{~m}$, a diameter of $0.25 \mathrm{~mm}$, the thickness of $0.25 \mu \mathrm{m}$, the temperature of $60-310^{\circ} \mathrm{C}$, helium gas as a carrier gas and an acceleration voltage of $70 \mathrm{ev}$. The FFA numbers were determined by an acid-base titration method using $0.1 \mathrm{~N} \mathrm{KOH}$. 
RASĀYAN J. Chem.

Vol. 14 | No. 2 |691-697| April - June | 2021

\section{Characterization of MWA-based Catalyst}

\section{RESULTS AND DISCUSSION}

The comparison of XRD diffractogram of the sample of M500, M600, M700, M800, and M900 and the JCPDS reference of calcite- $\mathrm{CaCO}_{3}$ have the crystal phase of rhombohedral was denoted as CR (PDF number 05-0586), aragonite- $\mathrm{CaCO}_{3}$ was denoted as $\mathrm{AO}$ (PDF number 41-1475) while having the crystal phase of orthorhombic. Portlandite- $\mathrm{Ca}(\mathrm{OH})_{2}$ have the crystal phase of hexagonal was denoted as $\mathrm{PH}$ (PDF number 44-1481), lime-CaO (denoted as LC) have the crystal phase of cubic (PDF number 371497), and nitratine- $\mathrm{NaNO}_{3}$ (denoted as NR) have the crystal phase of rhombohedral (PDF number 361474) as shown in Fig.-1.

The M500 showed the peaks at $29.41^{\circ}\left(\mathrm{d}_{\mathrm{hkl}}=104\right), 39.40^{\circ}(113), 43.14^{\circ}(202)$ according to calcite$\mathrm{CaCO}_{3}$. The pattern of M500 confirmed that the phase of lime-CaO and portlandite- $\mathrm{Ca}(\mathrm{OH})_{2}$ did not form at a calcination temperature of $500{ }^{\circ} \mathrm{C}$. Moreover, the calcite-rhombohedral crystal phase was only found at a calcination temperature of $500^{\circ} \mathrm{C}$. This fact as were an agreement with the previous investigation by Bazargan et al. ${ }^{17}$ The calcite degradation was not unprecedented at such a relatively low temperature, the decomposition of calcite to $\mathrm{CaO}$ occurs at a temperature in the range of $550-670{ }^{\circ} \mathrm{C}$ refer to the following reaction:

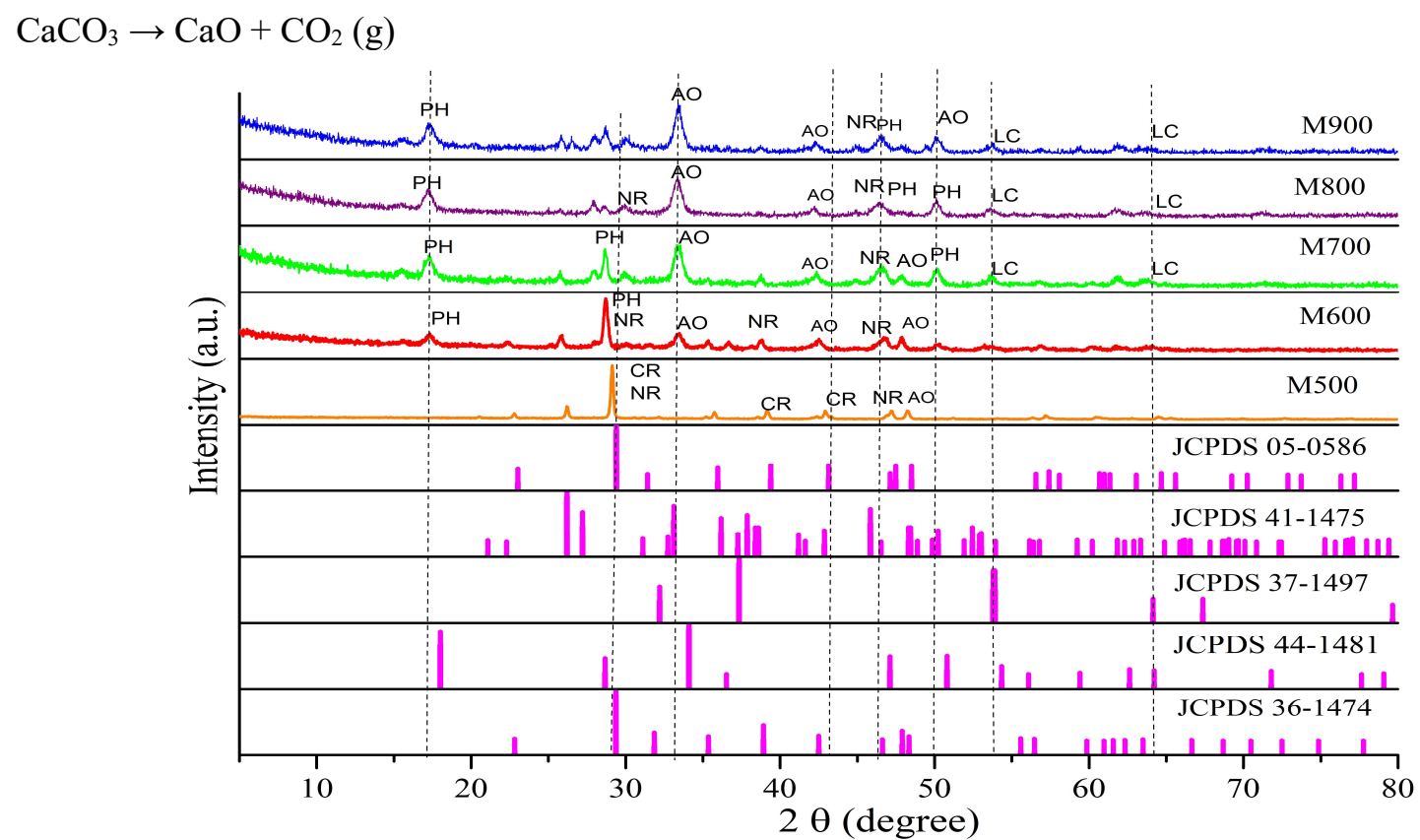

Fig.-1: XRD Pattern of MWA and the JCPDS References

Generally, the rhombohedral- $\mathrm{NaNO}_{3}$ crystal phase appeared at $46.64^{\circ}(024)$ for all of the temperature calcination. Furthermore, at 500 and $800^{\circ} \mathrm{C}$, a new peak of the nitratine- $\mathrm{NaNO}_{3}$ phase appeared at $29.41^{\circ}$ (104). This phase of $\mathrm{NaNO}_{3}$ was also observed at $600{ }^{\circ} \mathrm{C}$ with a peak appearance of $38.93^{\circ}$ (113). Not only the nitratine- $\mathrm{NaNO}_{3}$ phase was observed in all calcination temperatures but also aragonite- $\mathrm{CaCO}_{3}$. The peaks of this phase appeared at $33.45^{\circ}(012), 43.18^{\circ}(202), 47.49^{\circ}(018)$ at M600, M700, and M900. The M500 gives this characteristic peaks at $47.49^{\circ}(018)$, while the M800 appeared at $33.45^{\circ}(012)$, and $43.18^{\circ}(202)$. The hexagonal- $\mathrm{Ca}(\mathrm{OH})_{2}$ crystal phase was appeared at all of the temperature calcination, except for M500. The peaks were observed at $18.15^{\circ}(001), 29.38^{\circ}(104), 47.98^{\circ}(104)$, and $50.02^{\circ}(110)$. The lime-CaO phase-only was observed at $700-900{ }^{\circ} \mathrm{C}$ of calcination temperatures. This fact indicates were in previous agreement about the decomposition of calcite- $\mathrm{CaCO}_{3}$. This phase appeared at $53.84^{\circ}$ (220), and $64.15^{\circ}(311)$.

Table-1 indicates that the effect of various calcination temperatures on the basicity catalyst, while the pure $\mathrm{CaO}$ is a control base catalyst. As summarized in Table-1, it was observed that the calcination temperature affects the basicity value. The basicity of pure $\mathrm{CaO}$ obtained an optimum result of $2.30 \pm$ 
RASĀYAN J. Chem.

Vol. 14 | No. 2 |691-697| April - June | 2021

$0.07 \mathrm{mmol} \mathrm{HCl.g}{ }^{-1}$, as a reference for the commercial crystal. At a temperature of $500{ }^{\circ} \mathrm{C}$, the lowest basicity value is obtained. This is due to the $\mathrm{CaO}$ species has not yet been formed at this temperature that is the strongest base contributor, as confirmed by the results of XRD analysis. Based on XRD data it is known that there are three species of calcium oxide, namely $\mathrm{CaCO}_{3}, \mathrm{Ca}(\mathrm{OH})_{2}$, and $\mathrm{CaO}$.

According to Kouzu et al. that the basicity order of the calcium oxide species is $\mathrm{CaCO}_{3}<<\mathrm{Ca}(\mathrm{OH})_{2}<$ $\mathrm{CaO}$, which is proportional to its catalytic activity. ${ }^{20}$ The presence of these three species can be formed due to hydration and carbonation of the catalyst during calcination. This can be understood because $\mathrm{CaO}$ species are very reactive and react spontaneously with the environmental moisture of the system. Therefore the calcination temperature should be done above $900{ }^{\circ} \mathrm{C} .{ }^{21}$ Differences in basicity values in the MWA sample are influenced by the number and types of species contributing to their basicity. Based on the highest alkalinity value in the sample of calcination temperature at $700^{\circ} \mathrm{C}$, so $\mathrm{M} 700$ catalyst was then used in the transesterification catalytic activity test.

\section{The Catalytic Activity of MWA-based Catalyst in the Transesterification of LGPO}

The transesterification reaction involves the catalytically basic sites that allowed methanol to be transformed into nucleophiles. Furthermore, the nucleophile attacked carbonyl carbon in a molecule of glycerides. ${ }^{22}$ This means that the highest catalytic activity will be provided by a catalyst that has an optimal base. Referring to the CaO-catalyzed plant oil transesterification mechanism, Kuozo added that calcium methoxide is produced by the $\mathrm{CaO}$ reaction by simply stirring it into methanol at room temperature. ${ }^{22}$ Based on the experimental results above, it is concluded that M700 was expected to provide optimum catalytic activity in the variation of the amount of catalyst to methanol in the LGPO conversion.

Table-1: Total Basicity of MWA-based Catalyst with the Result of Calcination Temperature

\begin{tabular}{c|c}
\hline Catalyst & $\begin{array}{c}\text { Total Basicity } \\
\left(\mathrm{mmol} \mathrm{HCl.g} \mathrm{g}^{-1}\right)\end{array}$ \\
\hline Pure $\mathrm{CaO}$ & $2.30 \pm 0.07$ \\
\hline $\mathrm{M} 500$ & $0.84 \pm 0.05$ \\
\hline $\mathrm{M} 600$ & $1.27 \pm 0.06$ \\
\hline $\mathrm{M} 700$ & $2.15 \pm 0.05$ \\
\hline $\mathrm{M} 800$ & $1.93 \pm 0.04$ \\
\hline $\mathrm{M} 900$ & $2.09 \pm 0.04$ \\
\hline
\end{tabular}

The results of the varied amount of catalyst to methanol as shown in Fig.-2. Figure-2 showed the percentage of FFA reduction of the amount of $5 \%$ and $10 \%$, namely of $73.7 \pm 0.6(\%)$ to $89.0 \pm 0.6(\%)$, as compared to the FFA origin of LGPO was $1.5 \pm 0.3 \%$. The effect of catalyst weight up to $10 \%$ suggests that the increase in the active site of the catalyst which plays a role in the transesterification reaction causes an accelerate in catalytic activity, as an agreement with Fadhil et al. ${ }^{9}$ Furthermore, the addition of $15-20 \%$ catalyst weight caused the decrease in FFA to be slightly reduced, was about from $88.0 \pm 0.5(\%)$ to $75.0 \pm 0.7(\%)$. This is related to the number of active sites of the catalyst that have an optimal role in the reaction, when the reactants are adsorbed on the active site on the catalyst, one reactant is collected. Moreover, the adsorption of the next reactant molecules will be weak so that the formation of products will gradually decrease. This phenomenon due to the lower mass transfer between the solid base catalyst and FFA, as were an agreement with the previous investigation by Fadhil et al. ${ }^{9}$ Many variables, such as the acid content of the origin feedstock oil, the basic ability of the catalyst used, and the parameters used during the esterification, such as time, methanol to oil molar ratio, and temperature, may indeed be due to the differences optimal weight of the catalyst used in the transesterification process of different raw material oils. As a result, $10 \% \mathrm{w} / \mathrm{v}$ of the M700 solid base catalyst was selected as the optimal amount.

The spectra derived from the GC were analyzed using MS, and indeed the analysis of the mass spectra pattern was compared with the reference. Mass spectra exhibited that the major compounds in the performance of transesterification were methyl ester (biodiesel) with C15-C19 consisting of methyl myristate, methyl palmitate, methyl linoleate, methyl oleic, methyl stearate. These types of biodiesel 
RASĀYAN J. Chem.

Vol. 14 | No. 2 |691-697| April - June | 2021

compounds have a role in the quality of biodiesel. The two major components, namely methyl palmitate and methyl oleic have cetane numbers of 81.8 and $61.122,{ }^{23}$ respectively. Data on the percentage of fatty acid yield of the catalyst weight variation on methanol is presented in Fig.-3 with fatty acids before transesterification as a comparison.

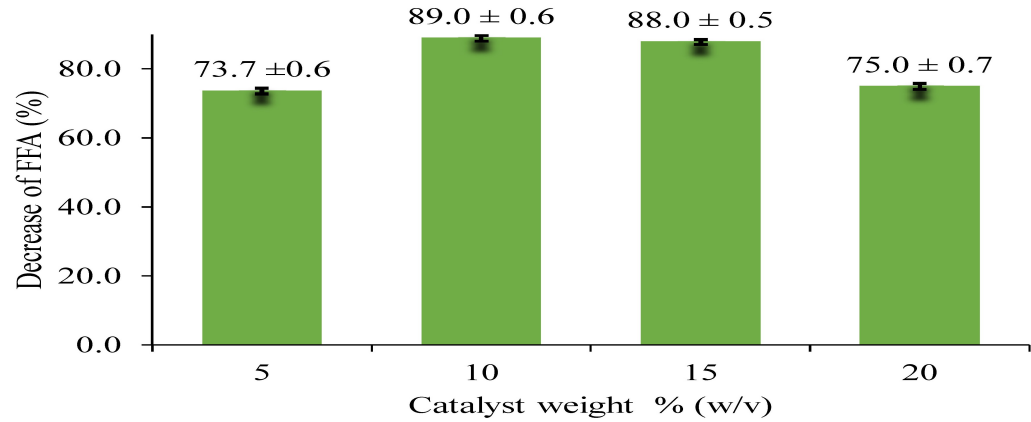

Fig.-2: Analysis of the Relation between the Decrease in LGPO Levels of FFA and the Weight of the Catalyst M700

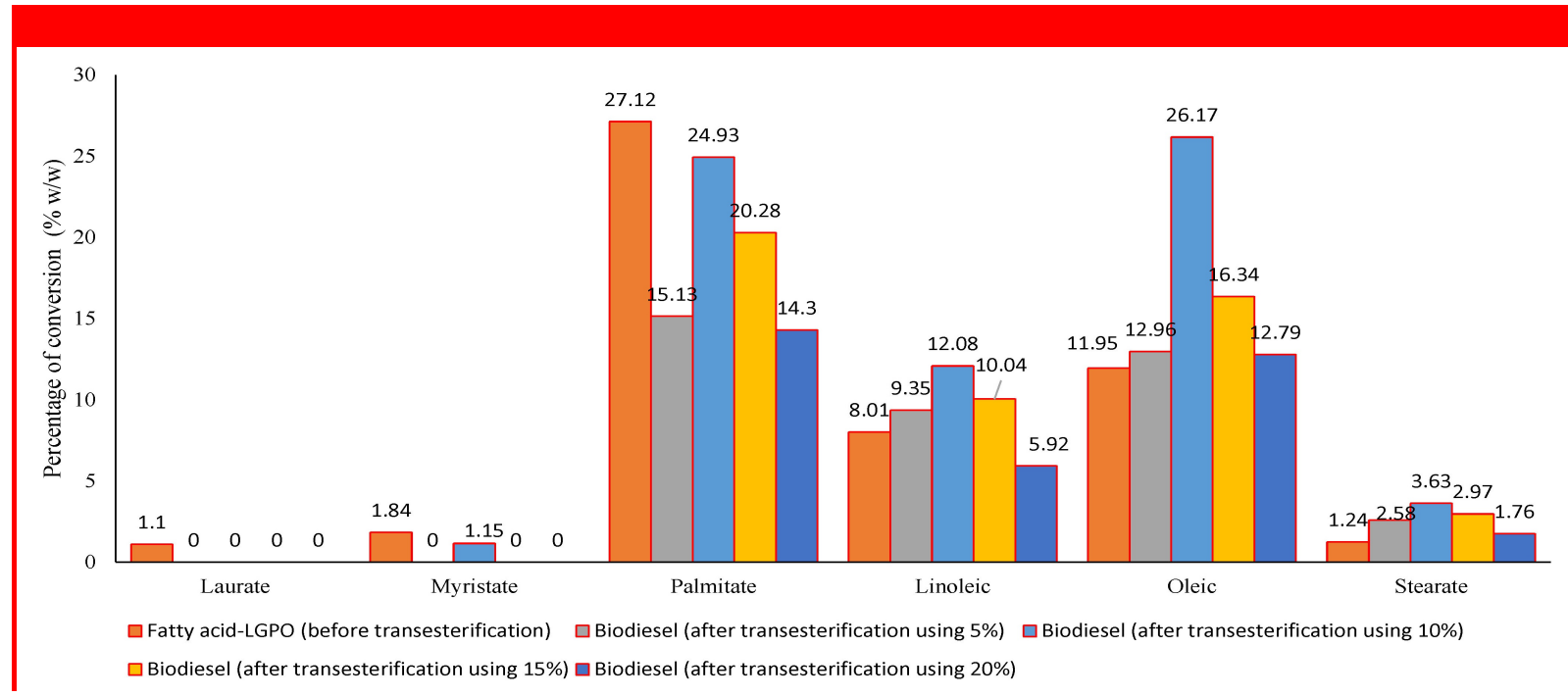

Fig.-3: Graph of the Percentage Yield of LGPO (before Esterification) and Biodiesel (after Esterification with

Various of the Catalyst Weight to Methanol)

Table-2: The Selectivity Product of the Biodiesel of the LGPO Transesterification using M700-based Catalyst

\begin{tabular}{|c|c|c|c|c|c|c|c|c|c|}
\hline \multirow{2}{*}{ Compound } & \multirow{2}{*}{$\begin{array}{l}\text { Molecule } \\
\text { Formula }\end{array}$} & \multicolumn{8}{|c|}{$\begin{array}{c}\text { Product Percentage }(\% \mathrm{w} / \mathrm{w}) \text { at a Varied Ratio of M700 Solid Base } \\
\text { Catalyst weight to Methanol }\end{array}$} \\
\hline & & $\begin{array}{l}\text { Peak } \\
\text { of \# }\end{array}$ & $5 \%{ }^{a}$ & $\begin{array}{l}\text { Peak } \\
\text { of \# }\end{array}$ & $10 \%^{\mathrm{b}}$ & $\begin{array}{l}\text { Peak } \\
\text { of \# }\end{array}$ & $15 \%{ }^{\mathrm{c}}$ & $\begin{array}{l}\text { Peak } \\
\text { of \# }\end{array}$ & $20 \%{ }^{\mathrm{d}}$ \\
\hline Methyl myristate & $\mathrm{C}_{15} \mathrm{H}_{30} \mathrm{O}_{2}$ & - & - & 2 & 0.8 & - & - & - & - \\
\hline Methyl palmitate & $\mathrm{C}_{17} \mathrm{H}_{34} \mathrm{O}_{2}$ & 3 & 9.6 & 3 & 17.9 & 4 & 16.0 & 1 & 8.4 \\
\hline Methyl linoleate & $\mathrm{C}_{19} \mathrm{H}_{34} \mathrm{O}_{2}$ & 4 & 5.9 & 4 & 8.7 & 5 & 7.9 & 2 & 3.5 \\
\hline Methyl oleic & $\mathrm{C}_{19} \mathrm{H}_{36} \mathrm{O}_{2}$ & 5 & 8.2 & 5 & 18.8 & 6 & 12.9 & 3 & 7.5 \\
\hline \multirow[t]{2}{*}{ Methyl stearate } & $\mathrm{C}_{19} \mathrm{H}_{38} \mathrm{O}_{2}$ & 6 & 1.6 & 6 & 2.6 & 7 & 2.3 & 4 & 1.0 \\
\hline & \multicolumn{2}{|c|}{ The Yield Total } & 25.3 & & 48.8 & & 39.1 & & 20.4 \\
\hline
\end{tabular}

a The biodiesel fraction of transesterification of LGPO (upper layer results as biodiesel fraction) by $5 \% \mathrm{w} / \mathrm{v}$ is $63.5 \% \mathrm{w} / \mathrm{w}$

${ }^{\mathrm{b}}$ The biodiesel fraction of transesterification of LGPO by $10 \% \mathrm{w} / \mathrm{v}$ is $72 \% \mathrm{w} / \mathrm{w}$

${ }^{c}$ The biodiesel fraction of transesterification of LGPO by $15 \% \mathrm{w} / \mathrm{v}$ is $78.7 \% \mathrm{w} / \mathrm{w}$

$\mathrm{d}$ The biodiesel fraction of transesterification of LGPO by $20 \% \mathrm{w} / \mathrm{v}$ is $58.6 \% \mathrm{w} / \mathrm{w}$

Based on Table-2 and Fig.-3, generally, it can be seen that the distribution shows that methyl palmitate is the major component found in all four variations except on the $10 \% \mathrm{w} / \mathrm{v}$ variation of the weight of 


\section{RASĀYAN J. Chem. \\ Vol. 14 | No. 2 |691-697| April - June | 2021}

catalyst to methanol. This is appropriate since the largest portion of palm oil triglycerides is palmitic acid as confirmed by Fig.-2. The yield total of biodiesel showed the optimum value at $10 \% \mathrm{w} / \mathrm{v}$ of $48.8 \%$, then followed by $15 \% \mathrm{w} / \mathrm{v}$ of $39.1 \%, 5 \% \mathrm{w} / \mathrm{v}$ of $25.3 \%$, and $20 \% \mathrm{w} / \mathrm{v}$ of $20.4 \%$.

\section{CONCLUSION}

In summary, the solid basic catalyst derived from Merbau wood waste ash has the highest total basicity value that synthesized of calcination temperature at $700{ }^{\circ} \mathrm{C}$, as confirmed by peak characteristic of the presence of lime- $\mathrm{CaO}$ species as the strongest base contributor, in addition to the presence of portlandite$\mathrm{Ca}(\mathrm{OH})_{2}$, calcite- $\mathrm{CaCO}_{3}$, aragonite- $\mathrm{CaCO}_{3}$, and nitratine- $\mathrm{NaNO}_{3}$. The $\mathrm{M} 700$ catalyst exhibited the highest catalytic activity, namely the yield total of biodiesel of $48.9 \%$ at the weight of catalyst to methanol of $10 \%$, while this catalyst showed the optimum decrease of FFA $(89.0 \pm 0.6 \%)$. The optimum conversion LGPO into biodiesel fraction optimum (78.7\%) was given by $15 \%$ of the weight of catalyst to methanol. Generally, the product selectivity of M700 at varied the weight of catalyst to methanol was palmitic acid. The results of this work showed that MWA agricultural waste could be used extensively to design a widely efficient, low-cost biodiesel synthesis base catalyst.

\section{ACKNOWLEDGEMENT}

This work was supported by the LPDP of the Ministry of the Finance Republic of Indonesia and the Ministry of Education and Culture of the Republic of Indonesia.

\section{REFERENCES}

1. I. Matos, E. Pérez-Mayoral, E. Soriano, A. Zukal, R.M. Martín-Aranda, A.J. López-Peinado, I. Fonseca and J. Čejka, Chemical Engineering Journal, 161(3), 377(2010), DOI:10.1016/j.cej.2009.09.040

2. D. Santi, Triyono, W. Trisunaryanti and I.I Falah, Journal of Environmental Chemical Engineering, 8(3), 103735(2020), DOI:10.1016/j.jece.2020.103735

3. A.D. Prasiwi, W. Trisunaryanti, T. Triyono, I.I. Falah, D. Santi and M.F. Marsuki, Indonesian Journal of Chemistry, 19(3), 575(2019), DOI:10.22146/ijc.34189

4. M. Li, F. Xu, H. Li and Y. Wang, Catalysis Science and Technology, 6(11), 3670(2016), DOI:10.1039/C6CY00544F

5. P. Kaewpengkrow, D. Atong and V. Sricharoenchaikul, International Journal of Hydrogen Energy, 42(29), 18397(2017), DOI:10.1016/j.ijhydene.2017.04.167

6. A.I. Casoni, M.L. Nievas, E.L. Moyano, M. Álvarez, A. Diez, M. Dennehy and M.A. Volpe, Applied Catalysis A: General, 514, 235(2016), DOI:10.1016/j.apcata.2016.01.017

7. A. Islam, Y.H. Taufiq-Yap, C.M. Chu, P. Ravindra and E.S. Chan. Renewable Energy, 59, 23(2013), DOI:10.1016/j.renene.2013.01.051

8. A.B. Fadhil, A.M. Aziz and M.H. Al-Tamer, Energy Conversion and Management, 108, 255(2016), DOI:10.1016/j.enconman.2015.11.013

9. D.K. Sarmah and D.C. Deka, Rasayan Journal of Chemistry, 12(3), 1547(2019), DOI:10.31788/RJC.2019.1235293

10. J. Nair, Y.V.V. Satyanarayana Murthy, M. Ramesh and G. Edeira, Rasayan Journal of Chemistry, 12(4), 1757(2019), DOI:10.31788/RJC.2019.1245273

11. G.H. Helmiyati, A.Y. Budiman and S. Ramadhani, Rasayan Journal of Chemistry, 13(1), 298(2020), DOI: $10.31788 /$ RJC.2020.1315497

12. L.C. Meher, V.S.S. Dharmagadda and S.N. Naik, Bioresource Technology, 97(12), 1392(2006), DOI:10.1016/j.biortech.2005.07.003

13. M. Saravanakumar, M. Prabhahar, S. Krishnamoorthi and S. Sendilvelan, Rasayan Journal of Chemistry, 11(1), 372(2018), DOI:10.7324/RJC.2018.1112024

14. T.N. Charyulu, P. Naveenchandran, E. Raja and R.N. Babu, Rasayan Journal of Chemistry, 13(2), 876(2020), DOI: 10.31788/RJC.2020.1325560

15. S. Benjapornkulaphong, C. Ngamcharussrivichai and K. Bunyakiat, Chemical Engineering Journal, 145(3), 468(2009), DOI:10.1016/j.cej.2008.04.036

16. G. Chen, R. Shan, J. Shi and B. Yan, Fuel Processing Technology, 133, 8(2015), DOI:10.1016/j.fuproc.2015.01.005 


\section{RASĀYAN J. Chem.}

Vol. 14 | No. 2 |691-697| April - June | 2021

17. A. Bazargan, M.D. Kostić, O.S. Stamenković, V.B. Veljković and G. McKay, Fuel, 150, 519(2015), DOI:10.1016/j.fuel.2015.02.046

18. M.R. Miladinović, M.V. Zdujić, D.N. Veljović, J.B. Krstić, I.B. Banković-llić and V.B. Veljković, Renewable Energy, 147, 1033(2020), DOI:10.1016/j.renene.2019.09.056

19. J.M. Supit, A.D.U Raharjo, J.V. Morin and N.P.P. Nugroho, In Proceedings of IOP Conference Series: Material Science and Engineering in International Conference in the Application of Technology and Engineering, Jakarta, Indonesia, pp.1-6 (2019), DOI:10.1088/1757899X/508/1/012087

20. M. Kouzu, T. Kasuno, M. Tajika, Y. Sugimoto, S. Yamanaka and J. Hidaka, Fuel, 87(12), 2798(2008), DOI:10.1016/j.fuel.2007.10.019

21. H. Zhu, Z. Wu, Y. Chen, P. Zhang, S. Duan, X. Liu and Z. Mao, Chinese Journal of Catalysis, 27(5), 391(2006), DOI: 10.1016/S1872-2067(06)60024-7

22. M. Kouzu and J.S. Hidaka, Fuel, 93, 1(2012), DOI:10.1016/j.fuel.2011.09.015

23. E.G. Giakoumis and C.K. Sarakatsanis, Energies, 12(3), 1(2019), DOI:10.3390/en12030422

[RJC-6238/2020] 